\title{
Penerapan Model Quantum Teaching dengan Multimedia untuk Meningkatkan Hasil Belajar IPA Tema Panas dan Perpindahannya pada Siswa Kelas V SDN Kebon Gunung Tahun 2019/2020
}

\author{
Siti Wahyuning Widi Pinasti ${ }^{1}$, Muhamad Chamdani ${ }^{2}$, Ngatman ${ }^{3}$ \\ 1,2,3Universitas Sebelas Maret \\ sitiwahyuning@student.uns.ac.id
}

\section{Article History}

accepted 01/10/2020

approved 01/11/2020

published 01/12/2020

\begin{abstract}
The study aimed to improve natural science learning outcomes to the theme of heat and its transfer to fifth grade students through the application of quantum teaching model with multimedia. It was a collaborative classroom action research conducted in three cycles. The subjects were the teacher and fifth grade students of Primary School Kebon Gunung. The results of showed that the application of quantum teaching model with multimedia improved natural science learning outcomes to the theme of heat and its transfer to fifth grade students of Primary School Kebon Gunung. It was proven by percentages of student mastery learning: $47.37 \%$ in the first cycle, $84.21 \%$ in the second cycle, and $94.73 \%$ in the third cycle. The obstacle was some students were shy to ask questions. The solution was the teacher motivated the students to ask questions. It concludes that the application of quantum teaching model with multimedia improves natural science learning outcomes to the theme of heat and its transfer to fifth grade students of Primary School Kebon Gunung in academic year of 2019/2020.
\end{abstract}

Keywords: quantum teaching, multimedia, natural science learning outcomes.

\begin{abstract}
Abstrak
Tujuan penelitian ini yaitu untuk meningkatkan hasil belajar IPA tema panas dan perpindahannya pada siswa kelas $\mathrm{V}$ melalui penerapan model quantum teaching dengan multimedia. Penelitian ini merupakan penelitian tindakan kelas kolaboratif yang dilaksanakan dalam tiga siklus. Subjek penelitian ini adalah guru dan siswa kelas V SDN Kebon Gunung. Hasil penelitian ini menunjukkan bahwa: penerapan model quantum teaching dengan mutimedia dapat meningkatkan hasil belajar IPA tema panas dan perpindahannya pada siswa kelas $\vee$ SDN Kebon Gunung yang dapat dilihat dari persentase rata-rat ketuntasan siswa yaitu 47,37\% pada siklus I, $84,21 \%$ pada siklus II, dan $94,73 \%$ pada siklus III. Kendala dalam penelitian ini yaitu siswa belum berani untuk mengajukan pertanyaan, adapun solusi dari kendala tersebut adalah guru membimbing siswa untuk berani bertanya. Kesimpulan dari penelitian ini adalah penerapan model quantum teaching dapat meningkatkan hasil belajar IPA tema panas dan perpindahannya pada siswa kelas V SDN Kebon Gunung Tahun 2019/2020.

Kata kunci: Quantum Teaching, multimedia, IPA
\end{abstract}




\section{PENDAHULUAN}

Pembelajaran IPA di Sekolah Dasar dapat memberikan siswa untuk mengembangkan kemampuan berpikir kritis, memupuk rasa ingin tahu yang tinggi dan mencari jawaban melalui pengamatan dan pegalaman langsung berdasarkan bukti. Menurut Winaputra (Samatowa: 2006) IPA tidak hanya merupakan kumpulan pengetahuan tentang benda atau makhluk hidup, tetapi merupakan cara kerja, cara berpikir, dan cara memecahkan masalah.

Berdasarkan observasi dan wawancara dalam pembelajaran IPA di kelas V SD Negeri Kebon Gunung diperoleh fakta-fakta: (1) siswa belum terlibat aktif dalam pembelajaran, (2) guru dalam menyampaikan materi melalui ceramah, (3) siswa sulit menerima materi IPA, (4) siswa kurang memahami istilah asing atau kata asing dalam materi IPA, (5) gaya belajar sebagian siswa hafalan yang membuat siswa itu fokus pada materi yang dipelajari saja, lalu jika terdapat soal berbeda dengan materi yang dipelajari maka mereka akan kebingungan dan sulit mengerjakannya.

Berdasarkan data yang diperoleh, diketahui bahwa proses pembelajaran di kelas V SDN Kebon Gunung belum dilaksanakan secara optima. Hal ini juga terbukti dengan hasil nilai PTS (Penilaian Tengah Semester) mata pelajaran IPA masih rendah dan banyak yang belum memenuhi Kriteria Ketuntasan Minimal (KKM) yang diterapkan sekolah yaitu 68. Nilai rata-rata kelas hanya mencapai 63,63 dari 19 siswa. Dari 19 siswa kelas V, terdapat 8 siswa yang sudah tuntas atau sebesar $43 \%$. Sedangkan sebanyak 11 siswa yang belum tuntas atau sebesar $57 \%$.

Peran dan keberadaan guru sangat penting dalam proses pembelajaran. Guru berperan sebagai pembimbing dan fasilitator sehingga proses pembelajaran dapat berlangsung dengan baik dan lancar. Kebanyakan guru mengajar masih konvensional, misalnya penggunaan metode ceramah, tanya jawab dan penugasan yang membuat pemahaman siswa masih kurang. Berdasarkan uraian tersebut, maka peneliti bermaksud melaksanakan penelitian tindakan kelas yang berkolaborasi dengan guru kelas $\mathrm{V}$ untuk meningkatkan hasil belajar IPA di kelas $\mathrm{V}$.

Model yang diterapkan harus model yang dapat membuat siswa aktif dalam pembelajaran. Wibowo, Warsiti, dan Ngatman (2015) menyatakan bahwa model quantum teaching merupakan salah satu model pembelajaran yang memfokuskan siswa dalam pembelajaran yang dapat meningkatkan keaktifan dan motivasi siswa. Dalam penelitiannya, Silalahi (2017) mengungkapkan bahwa model quantum teaching dapat menciptakan suasana kelas yang kondusif dan menyenangkan melalui rancangan model pembelajarannya. Rancangan pembelajaran tersebut dikenal dengan istilah "TANDUR", yang merupakan kepanjangan dari: Tumbuhkan, Alami, Namai, Demonstrasikan, Ulangi, Rayakan.

Selain model pembelajaran, pemilihan media juga dapat membantu pemahaman siswa dalam pembelajaran. Asyhar (2011: 45) menjelaskan bahwa multimedia yaitu media yang melibatkan beberapa media yang terintegrasi dalam suatu kegiatan pembelajaran. Menurut Alkhasawneh (2016: 96) multimedia mencakup lebih dari satu bentuk media seperti konferensi teks, grafik, animasi, audio, video animasi, dan video yang mampu memberikan rangsangan.

Berdasarkan uraian tersebut rumusan masalah dalam penelitian ini adalah 1) bagaimana penerapan model quantum teaching dengan multimedia untuk meningkatkan hasil belajar IPA tentang tema panas dan perpindahannya pada siswa kelas V SDN Kebon Gunung tahun 2019/2020?, 2) apakah model quantum teaching dengan multimedia dapat meningkatkan hasil belajar IPA tentang tema panas dan perpindahannya pada siswa kelas V SDN Kebon Gunung tahun 2019/2020?, dan 3) apakah kendala dan solusi dalam penerapan model quantum teaching dengan multimedia untuk meningkatkan hasil belajar IPA tentang tema panas dan perpindahannya pada siswa kelas V SDN Kebon Gunung tahun 2019/2020?. 
Tujuan penelitian ini adalah 1) untuk mendeskripsikan penerapan model quantum teaching dengan multimedia untuk meningkatkan hasil belajar IPA tema panas dan perpindahannya pada siswa kelas $V, 2$ ) meningkatkan hasil belajar IPA tema panas dan perpindahannya pada siswa kelas $\mathrm{V}$ melalui penerapan model quantum teaching dengan multimedia, 3) mendeskripsikan kendala dan solusi dalam penerapan model quantum teaching dengan multimedia untuk meningkatkan hasil belajar IPA tema panas dan perpindahannya pada siswa kelas $\mathrm{V}$.

\section{METODE}

Metode penelitian ini yaitu penelitian tindakan kelas kolaboratif dengan tiga siklus yang dilaksanakan di SD Negeri Kebon Gunung dengan subjek guru dan siswa kelas V dan siswa yang berjumlah 19 siswa dengan rincian 8 siswa laki-laki dan 11 siswa perempuan.

Data yang diperoleh bersumber dari guru dan siswa kelas $\mathrm{V}$. teknik pengumpulan data yang digunakan adalah tes dan nontes. Data yang diperoleh berupa data kuantitatif dan kualitatif. Validitas data diuji dengan teknik triangulasi sumber. Kemudian data dianalisis menggunakan pendapat Miles dan Huberman (Sugiyono, 2015: 337-345) yang meliputi reduksi data, penyajian data, dan penarikan kesimpulan.

Indikator kinerja penelitian yang ditargetkan adalah 85\% untuk penerapan model quantum teaching dengan multimedia dalam pembelajaran IPA dan hasil belajar siswa dengan KKM 70 sebesar 85\%. Prosedur penelitian tindakan ini menurut Kemmis dan Taggart (Arikunto, 2013: 137) meliputi empat tahapan yaitu perencanaan, pelaksanaan, pengamatan, dan refleksi.

\section{HASIL DAN PEMBAHASAN}

Pelaksanaan tindakan ini dilaksanakan selama 3 siklus. Penelitian tindakan ini menggunakan langkah-langkah model quantum teaching dengan multimedia yaitu: a) tumbuhkan dengan multimedia pada langkah ini guru menumbuhkan motivasi belajar siswa dengan mengajaknya bernyanyi dengan menampilkan media video yang berisi teks lagu yang dinyanyikan bersama, b) alami dengan multimedia pada langkah ini guru menayangkan media teks powerpoint dan gambar, c) namai kegiatan pada langkah ini siswa melakukan diskusi dengan teman sekelompoknya, d) demontrasikan kegiatan pada langkah ini siswa menyampaikan hasil diskusi didepan kelas, e) ulangi dengan multimedia pada langkah ini guru mengulang kembali materi yang sudah diajarkan dari awal dengan menampilkan media teks powerpoint yang berisikan rangkuman materi, dan f) rayakan dengan multimedia pada langkah ini guru memberikan apresisasi kepada siswa dengan menayangkan media video animasi.

Langkah-langkah model quantum teaching yang telah dilaksanakan sesuai dengan rancangan model quantum teaching yang dijelaskan Yahya (2017: 159-162) yang sesuai dengan kerangka rancangan Quantum Teaching, yaitu TANDUR yang dilaksanakan dengan 6 langkah sebagai berikut: (1) tumbuhkan, adalah menumbuhkan minat siswa dan menumbuhkan suasana yang menyenangkan dan menggembirakan, (2) alami, adalah memberikan pengalaman belajar kepada siswa, (3) namai, adalah memberikan kata kunci, konsep, model atau rumus atas pengalaman yang telah diperoleh siswa, (4) demonstrasikan, adalah memberikan kesempatan kepada siswa untuk menerjemahkan dan menerapkan pengetahuan mereka, (5) ulangi, adalah melakukan pengulangan dalam kegiatan pembelajaran yang nantinya dapat menumbuhkan rasa yakin terhadap kemampuan siswa, (6) rayakan, adalah memberikan pengakuan terhadap penyelesaian dan perolehan kemampuan siswa. 
Data hasil observasi penerapan model quantum teaching dengan multimedia oleh guru dan siswa pada siklus I, II, III sebagai berikut:

Tabel 1 Hasil Observasi Penerapan Model Quantum Teaching dengan Multimedia

\begin{tabular}{lccc}
\hline & \multicolumn{3}{c}{ Siklus } \\
\cline { 2 - 4 } & I & II & III \\
\hline Guru (\%) & $78.81 \%$ & $85.94 \%$ & $90.76 \%$ \\
\hline Siswa (\%) & $76.05 \%$ & $84.46 \%$ & $90.07 \%$ \\
\hline
\end{tabular}

Berdasarkan tabel 1 di atas, observasi terhadap guru pada siklus I menghasilkan persentase sebesar $78,81 \%$ dan pada siklus II menjadi $85,94 \%$. Antara siklus I dan II meningkat $7,13 \%$. Pada siklus III meningkat $4,82 \%$ menjadi $90,76 \%$, sehingga sudah mencapai hasil yang sangat baik.

Hasil observasi terhadap siswa pada siklus I menghasilkan persentase sebesar $76,05 \%$ dan pada siklus II menjadi $84,46 \%$. Antara siklus I dan II meningkat $8,41 \%$. Pada siklus III terjadi peningkatan sebesar 5,61\% menjadi $90,07 \%$, artinya sudah memenuhi indikator kinerja yaitu $85 \%$. Berdasarkan data tersebut dapat diketahui bahwa dalam setiap siklus penelitian mengalami peningkatan yang sangat baik. jadi dapat disimpulkan bahwa penerapan model quantum teaching dengan multimedia dapat meningkatkan hasil belajar IPA tema panas dan perpindahannya pada siswa kelas V SD Negeri Kebon Gunung.

Selain proses pembelajaran yang dilaksanakan guru dan siswa dengan menerapkan model quantum teaching dengan multimedia berikut disajikan perbandingan ketuntasan hasil belajar tes tertulis siswa pada siklus I, II, III.

Tabel 2 Perbandingan Hasil Belajar Siswa Siklus I, II, dan III

\begin{tabular}{lccc}
\hline & \multicolumn{3}{c}{ Siklus } \\
\cline { 2 - 4 } & I & II & III \\
\hline Tuntas & $47,37 \%$ & $84,21 \%$ & $94,73 \%$ \\
\hline Belum Tuntas & $52,63 \%$ & $15,79 \%$ & $5,27 \%$ \\
\hline
\end{tabular}

Berdasarkan tabel 2 di atas, dapat dilihat bahwa ketuntasan hasil belajar siswa mengalami peningkatan di setiap siklus. Persentase ketuntasan siswa pada siklus I yaitu $47,37 \%$, naik menjadi $84,21 \%$ pada siklus II, dan $94,73 \%$ pada siklus III merupakan hasil yang sangat baik serta telah memenuhi indikator kinerja yaitu $85 \%$ sehingga peneliti mengakhiri penelitian ini. Berdasarkan hasil tersebut dapat disimpullkan bahwa model quantum teaching dengan multimedia dapat meningkatkan hasil belajar IPA tema panas dan perpindahannya pada siswa kelas V SD Negeri Kebon Gunung.

Berdasarkan penelitian Yanuarti dan Sobandi (2016: 14) menyatakan bahwa model quantum teaching adalah model yang dapat meningkatkan hasil belajar siswa karena menggunakan prinsip sugesti yang dapat mempengaruhi hasil belajar dan menekankan kreativitas siswa agar lebih aktif dalam proses pembelajaran sehingga siswa dapat mengembangkan pemahaman mereka. Sehingga dalam pembelajaran siswa dapat mengembangkan pemahamannya sendiri berdasarkan pengalaman yang ada dalam kehidupan sehari-hari dan kreativitas serta keaktifan yang dapat meningkatkan hasil belajar. Keaktifan dapat mempengaruhi hasil belajar siswa, hal ini dikarenakan dengan siswa aktif membuat siswa lebih memahami materi dan akan mudah disimpan di dalam memorinya.

Pembelajaran yang dilakukan dengan menerapkan model quantum teaching dengan multimedia yang dilaksanakan selama tiga siklus menemui beberapa kendala 
yaitu: a) beberapa siswa belum termotivasi belajar, b) beberapa siswa belum memahami kebermaknaan materi yang sedang dipelajari, c) beberapa siswa belum andil dalam berkerja sama mengerjakan LKS, d) beberapa siswa belum berani menanggapi presentasi kelompok lain, e) beberapa siswa masih pasif saat guru melakukan tanya jawab, dan f) beberapa siswa membuat suasana di kelas ramai ketika mendapatkan hadiah. Adapun solusi dari kendala tersebut, yaitu: a) siswa memperhatikan video motivasi yang ditayangkan guru, b) siswa menghubungkan materi dengan pengalaman yang pernah dialami sebelumya, c) guru mengawasi kerja setiap kelompok, d) guru menfasilitasi kelompok untuk saling menanggapi saat mempresentasikan hasil LKS, e) guru merangsang siswa untuk berani bertanya dan menjawab, f) siswa dibiasakan untuk tertib dalam mengikuti pembelajaran, dan g) setiap anggota kelompok mengingatkan untuk saling bekerja sama dalam mengerjakan LKS.

\section{SIMPULAN}

Berdasarkan hasil penelitian yang diperoleh, maka dapat disimpulkan bahwa hasil belajar IPA tema panas dan perpindahannya dapat meningkat melalui penerapan model quantum teaching dengan multimedia yang dilaksanakan dengan langkahlangkah (1) tumbuhkan dengan multimedia, (2) alami dengan multimedia, (3) namai, (4) demontrasikan, (5) ulangi dengan multimedia, dan (6) rayakan dengan multimedia. Penerapan model quantum teaching dengan mutimedia dapat meningkatkan hasil belajar IPA tema panas dan perpindahannya pada siswa kelas V SDN Kebon Gunung tahun 2019/2020. Hal tersebut dapat dilihat dari persentase ketuntasan siswa yaitu 47,37\% pada siklus I, $84,21 \%$ pada siklus II, dan 94,73\% pada siklus III. Kendala dalam penelitian ini yaitu a) siswa belum dapat bekerjasama dengan baik, b) siswa belum aktif dalam bertanya dan menyampaikan pendapat. Adapun solusi untuk kendala tersebut yaitu a) guru mengawasi dan memberi teguran kepada siswa untuk bekerjasama, b) guru membimbing dan memotivasi siswa untuk berani bertanya dan menyampaikan pendapat.

Berkaitan dengan hasil penelitian, peneliti memberikan saran sebagai berikut: (1) Bagi siswa, fokus terhadap pembelajaran dan meningkatkan keberanian bertanya, (2) Bagi guru, guru mampu mengarahkan siswa untuk aktif belajar, (3) Bagi sekolah, sekolah menyediakan fasilitas, sarana, dan prasarana pembelajaran yang lengkap serta mendukung guru untuk meningkatkan kualitas pembelajaran, (4) Bagi peneliti lain, dapat dijadikan referensi untuk melakukan penelitian.

\section{DAFTAR PUSTAKA}

Alkhasawneh, S. (2016). The Effect of Multimedia-Aided Teaching on Kindergarten Children Mathematical Achievement and Attitude, Paripex Indian Journal of Reasearch, 5 (4) 96 - 98

Arikunto, S. (2013). Prosedur Penelitian: Suatu Pendekatan Praktik. Jakarta: Rineka Cipta

Asyhar, H. R. (2011). Kreatif Mengembangkan Media Pembelajaran. Jakarta: Gaung Persada

Samatowa, U. (2006). Bagaimana Pembelajaran IPA di Sekolah Dasar. Jakarta: Departemen Pendidikan Nasional Direktorat Jenderal Pendidikan Tinggi Direktorat Ketenagaan

Silalahi, W. (2017). Penerapan Model Quantum Teaching untuk Meningkatkan Aktivitas Belajar IPA Siswa Kelas V SDN 060822 Medan. School Education Journal, 7 NO. 2

Sugiyono. (2015). Metode Penelitian Kuantitatif, Kualitatif, dan R\&D. Bandung: Alfabeta 
Volume 8 Nomor 3 Tahun 2020

Wibowo, E. S., Warsiti, dan Ngatman. (2015). Penggunaan Model Quantum Teaching untuk Meningkatkan Kualitas Pembelajaran IPA pada Siswa Kelas IV SDN 7 Kebumen. Jurnal Kalam Cendekia PGSD Kebumen, 3 (3.1) 264-269

Yahya, H. (2017). Pengaruh Penerapan Model Pembelajaran Quantum Teaching Terhadap Hasil Belajar Biologi Siswa SMS IT Al-Fityan Gowa, Jurnal Biotek, 5 (1) 155 - 156.

Yanuarti, A., dan Sobandi, A. (2016). Upaya Meningkatkan Hasil Belajar Siswa Melalui Penerapan Model Pembelajaran Quantum Teaching. Jurnal Pendidikan Manajemen Perkantoran, 1 (1) 11-18 